in the second progress report of the Institute of Welding. Further evidence is given of the increased applications by the issue of official regulations and specifications for welded steelwork by national bodies in many countries. Some manufacturers think that tho welding industry may ultimately employ as much capital and labour as the steel industry now does. Such considerations apply equally to shipyards. and remembering the inherent water, oil and gas tightness of welded vessels, the rate of advance in the uso of welding in shipyards will doubtless advance more rapidly in the future. The progressive widening of applications is producing fresh problems. Large. scale operations indicate the desirability of carrying out as much as possible of the actual welding in specially dovised workshops rather than at the ship. building berth. This requirement will sometimes entail the re-design of component sections to render them more transportable and also the provision of suitable and adequate manipulative and adequate lifting equipment.

\section{Johannesburg Municipal Bus and Tram Sheds}

THE all-welded structure of the new municipal bus and tram sheds at Johannesburg is claimed to cover an area greater than that of any other wolded structure in South Africa. In Electric Welding of August, it is stated that, excluding an office block of reinforced concrete, the building has a frontage of 465 feet and an area of approximately 186,000 square feet. The outer walls are of concrete but all the interior walls are steel-framed. The floor is of con. crete throughout. To give unobstructed floor space, the number of columns was cut down to a minimum. Tho largest of the girders span 90 feet and are 12 feet deep. They were dispatched by road from the company's workshops at Benoni, whero all the steelwork was fabricated. To allow of transportation through Johannesburg, they were split into halves, tho halves being welded together at the site and the girders lifted in one pieco. A striking feature of the design is the absence of gusset plates and the lightness of all the sections employed. The entiro framework is welded, including even the site connexions. The saw-toothed type of roof employed produces oxcellent internal lighting. The percentage of windows to floor spaco is about thirty. The lamps provided are of the mercury vapour type. Botween 500 and 600 tons of steel were used in the erection of the sheds, the greater portion of this steelwork being produced in South Africa.

\section{Electric Lighting in a Modern Store}

IN Welwyn Garden City, Herts, an entirely now building now houses tho Welwyn Stores; a closcription of the building is given in the Electrical Review of October 13. The Velwyn Electricity Supply Co. built and equipped a new sub-station near the site to meet the required demand. The G.E.C. Co., Ltd., installed the whole of the lighting and fittings for 336 combined tungsten and Osira lamps. The outside illumination consists of four large neon signs. The shop fronts have artificial stone piers, marble risers and a painted wooden facia and cornice in which is set a line of fluorescent tubing running round three sides of the building. About 900 feet of 'Clora' coated tubing has been used for this purpose. The store itself comprises ground floor and part of the first floor. Under an artificial daylight effect achioved by 'T.O.T.' units, the natural waxpolished oak counters, stock fittings and panelling show up well. During the daytime, the daylight entering the ground floor through 'glass-crete' rooflights from the staircaso blends with the artificial illumination, all strong contrasts being eliminated. Each lighting unit consists of ono 80-watt 'Osira' fluorescent type discharge lamp and threo 150-watt tungsten lamps enclosed in opal sphere pendants 18.in. in diameter. All the main selling floors have this typo of lighting. The food hall is a separate section on the ground floor. There are 1,400 feet of fluorescent tubing, arranged round the ceiling in three parallel rows-ono red tube and two bluoand the effect of this diffused brilliance is enhanced by the green and white chequered flooring, the tiled walls and counter fronts, and other modern fittings. Light signalling by pro-arranged combinations of four different colours is used throughout the storo for attracting the attention of managers or other persons.

\section{Soil Science at Adelaide}

THE Winter School in Soil Science held during August 14-23 at the Waite Agricultural Research Institute, Adelaide, was a signal success. It was sponsored by the Council for Scientific and Industrial Research and the University of Adelaide and met under the chairmanship of Prof. J. A. Prescott. Sixty members attended, all directly engaged in work on soils, and representative of universities, State departments of agriculture and of forestry, water supply commissions, Government chemical labora. tories and other interests. Papers were presented on classification, physical composition, colour, water relations, acidity and lime requirement of soils; methods of soil surveying and utilization of soil maps and data; spectrochemical and polarographic methods of analysis; methods for determination of soil carbon, soil reaction and soluble salts; the erosion problem in pastoral areas; and other topics. Numorous demonstrations were arranged. As a result of the School, soil investigators throughout tho Commonwealth will in future be working in more intimate association and along more uniform lines.

\section{Rare Medical Books}

ON the occasion of the seventieth birthday earlier this year of the late Prof. Harvey Cushing, Schuman's of New York brought out, under the title of "Seventy Noteworthy Medical Rarities", an illustrated and annotated catalogue to which are prefixed a portrait of Dr. Cushing, taken about forty years ago, and an appreciation of the eminent surgeon and bibliophile by Dr. Lawrence Reynolds. Among the notable works listed in the 